\title{
An Overview of Respiratory Diseases in Pets
}

\author{
Bulent Elitok* \\ Department of Internal Medicine, AfyonKocatepe University, Turkey
}

Received: April 25, 2018; Published: July 03, 2018

*Corresponding author: Bulent Elitok, Department of Internal Medicine,Faculty of Veterinary Medicine,AfyonKocatepe University, 03200/

Afyonkarahisar, Turkey,Email: elitok1969@hotmail.com

Abstract

Respiratory tract diseases are most commonly seen in pets. Bacteria, viruses, mycoplasms and fungal ethiologic pathogens play an important role in the formation of the disease. Clinical signs such as coughing and dyspnea are commonly referable to primary problems of the respiratory tract. Useful diagnostic methods are avaliable. Treatment options vary by cases.

Keywords: Respiratory diseases;Pets; Diagnosis;Treatment

\section{Introduction}

Respiratory diseases are common in dogs and cats. Although clinical signs such as coughing and dyspnea are commonly referable to primary problems of the respiratory tract, they may also occur secondary to disorders of other organ systems (eg, congestive heart failure).

Varying floras of indigenous commensal organisms (including Pasteurella multocida, Bordetella bronchiseptica, streptococci, staphylococci, pseudomonads, and coliform bacteria) normally reside in the canine and feline nasal passages, nasopharynx, and upper trachea, and at least intermittently in the lungs, without causing clinical signs. Opportunistic infections by these bacteria may occur when respiratory defense mechanisms are compromised by infection with a primary pathogen (eg, distemper, parainfluenza virus, or canine type 2 adenovirus in dogs, and rhinotracheitis virus or calicivirus in cats), other insults (eg, inhalation of smoke or noxious gases), or diseases such as congestive heart failure and pulmonary neoplasia. Secondary bacterial infections complicate the management of viral respiratory infections of both dogs and cats [1].

\section{Rhinitis and sinusitis}

Rhinitis is the inflammation of the nose and muscular membranes. Sinusitis is the inflammation of paranasal sinuses. In general, bacteria are involved in the sequelae of viral agents as a result of degradation of the mucosal barrier [2-4]. Isolation of the agents and other auxiliary symptoms such as clinical signs are diagnosed [5].

Considering the complications of the disease, surgical or drug treatment methods are being tried. Surgically; excision can be performed such as nasopharyngeal polyp extraction in the ked is with rhinotomy and turbinectomy. In treatment with medication; sulphonamide or tetracycline, lavage of mucopurulent currents may be tried. Fungal rhinitis; antifungal drugs such as ketoconazole are applied. Allergic rinitte; antihistamines and corticosteroids are indicated [6,7].

\section{Tracheobronchitis}

Trachea and bronchi are inflamed and cough is obvious. Slight pressure on the trachea can trigger coughing. Bordatellabrochibiseptica Pseudomonas spp., E. coli, Klebsiella spp., Pasteurella spp., Streptococcus spp., Bacteria and Mycoplasma species are effective in the development of the disease $[7,8]$. Mild leucopenia in the early period may suggest viral infection. Neutrophilic leukocytosis with severe left pneumonitis can frequently occur with severe pneumonitis [7].

Antibiotics such as amoxicillin/clavulonic acid, gentamicin, doxycycline, and bronchodilators such as theophylline can be used to prevent bronchospasm $[9,10]$.

\section{Bronchopneumonia}

Bacterial, fungal, allergic, aspiration or parasitic factors play a role in the pathogenesis of the disease. The presence of FIV and FeLV may be associated with mycotic pneumonia [11].

Clinical, haematological and blood gas measurements provide an important clue to the diagnosis of the disease. Respiratory acidosis develops, $\mathrm{PaO} 2$ falls, $\mathrm{PaCO} 2$ concentration increases. Tracheal lavage, bronchoalveolar lavage, thoracic radiography, bronchoscopy and pulmonary aspirate examinations are used. Allergies are tested in allergic conditions $[3,12]$. 
Corticosteroids may be used in allergic cases, and antibiotics such as amoxycillin + clavulanic acid and metronidazole may be useful in the case of bacterial cases. In mycotic infections, itraconazole or ketoconazole is indicated $[7,13]$.

\section{Pneumonia}

The lung is the fire of paranoid doctrine. Cough, fever, dyspnoea, abnormal breathing sounds on ejaculation, weight loss, peripheral lymph endothelium are frequently encountered findings[14].

Chestradiography, bronchoscopy, and cytological examination of aspirates together with clinical and haematological findings help definite diagnosis $[13,15]$. Left-shift or neutrophil-derived leucocytosis can occur in haematological examinations. In cases of hyperglobulinemia, dirofilariasis should be considered. Antibiotics, antimycotics against mycoplasma, and cortisone preparations up to the level of clinical findings can be used in cases of bacterial pneumonia [16].

\section{Aspiration pneumonia}

Focal anomalies, paralysis, obstructions, oesophagus anomalies, mega-oesophageal, broncho-esophagal fistula, sedation and anaesthesia result, frontal lobe diseases, malformations due to fornication [17]. Bordetella bronchiectasis, Streptococcus zooepidermicus, Mycoplasma spp., E. coli, Klebsiella, Pasteurella multicoda, Staphylococcus spp. Streptococcus spp. Pseudomonas aeruginosa is the most common cause $[5,18]$.

Neutrophilic leucocytosis, left-shift, and sometimes nonregenerative anemia can be formed in addition to clinical symptoms such as cough, fever, and respiratory failure [7].

Radiography, tracheal lavage, bronchoscopy can help. In therapy; bronchodilators such as lavage, antibiotic treatments, antifungal drugs and theophylline, and short-term corticosteroids are indicated [13].

\section{Pleural effusions}

There is a fluid accumulation between the Pleura leaves. Increase in hydrostatic pressure in the circulation (right heart failure), increase in permeability in vascular endothelium, obstruction of lymphatic flow and haemorrhage. Dogs and cats are often traumatized[7,14].

Dyspnoea, tachypnoea and hyperpnea are the most common symptoms and become more evident in exercise and stress situations. In the case of anus, lung sounds cannot be heard or heard as if coming from a distance. Horizontal stretch is taken at the percussion $[7,18]$.

If the concentration of LDH in the pleural fluid is <200IU/L, fluid is transudate,if $>200 \mathrm{IU} / \mathrm{L}$, it is defined as exudate. If glucose in the fluid is lower than blood serum, prothorax or malignant causes should be considered. If fluid accumulation is not detected in the pleural space on ultrasonographic examination, thoracentesis is contraindicated for the risk of pneumothorax $[7,14]$.

\section{Pyothorax}

Pleura leaves are irritated. Pleural fluid dyspnoea and septicemic systemic changes (fever, increased respiration and pulse rate, general impairment, depression) are caused by the iris character. Radiologic, ultrasonographic lung examinations and thoracentesis were performed [4].In therapy; thoracocentesis is performed and the pus on both sides is aspirated. High doses of amoxicillin, metronidazole or fluoroquinolones can be used for a long time $[12,19,20]$.

\section{Pneumothorax}

Pleural air is gathering in the space. It is usually shaped by trauma. Acute respiratory distress, tachypnoea, cyanosis and cervical subcutaneous emphysema are the most striking findings. Respiratory voices have decreased in osculating. On the radiograph, the heart is seen away from the sternum. In therapy $[5,7,13]$ with oxygen inhalation, sewing thoracic wound, artificial respiration or thoracostomy.

\section{References}

1. Kuehn NF. (2017) MSD Veterinary Manuel.

2. Mochizuki M, Yachi A, Ohshima T, Ohuchi A, Ishida T (2008) Etiologic study of upper respiratory infections of household dogs. J Vet Med Sci 70: 563-569.

3. Padrid P (1992) Chronic Lower airway disease in the dog and cat. Probl Vet Med 4(2): 320-344.

4. Viitanen SJ, Lappalainen A, Rajameaki MM (2015) Co-infections with respiratory viruses in dogs with bacterial pneumonia. J Vet Intern Med 29(2): 544-551.

5. Greene CE (1998) Infectius diseases of the dog and cat. ( $2^{\text {nd }}$ edn), Saunders, Philadelphia, USA.

6. Chandler JC, Lappin MR (2002) Mycoplasmal respiratory infections in small animals: 17 cases (1988-1999). J Am Anim Hosp Assoc 38: 111119.

7. Ettinger S, Feldman E, Cote E (2016) Textbook of Veterinary Internal Medicine: Diseases of the Dog and the Cat, Expert Consult. ( $8^{\text {th }}$ edn), Elsevier, USA.

8. Bemis DA (1992) Bordetella and mycoplasma respiratory infection in dogs. Vet Clin North Am Small Anim Pract 22(5): 1173-1186.

9. Wong DM, Blumberg DA, Lowe LG (2006) Guidelines for the use of antimicrobials in acute upper respiratory tract infections. Am Fam Physician 74(6): 956-966.

10. Zhu BY, Johnson LR, Vernau W (2015) Tracheobronchial brush cytology and bronchoalveolar lavage in dogs and cats with chronic cough: 45 cases (2012-2014). J Vet Intern Med 29(2): 526-532.

11. McKiernan BC (2000) Diagnosis and treatment of canine chronic bronchitis. Twenty years of experience. Vet Clin North Am Small Anim Pract 30(6): 1267-1278.

12. Johnson MS, Martin MW (2007) Successful medical treatment of 15 dogs with pyothorax. J Small Anim Pract 48(1): 12-16.

13. Hawkins EC (1992) Tracheal wash and bronchoalveolar lavage in the management of respiratory disease. In: Kirk RW, Bonagura JD (Eds.), 
Current veterinary therapy XI. Saunders, Philadelphia, USA, pp: 795800 .

14. Bauer T (1989) Pulmonary hypersensitivity disorders. In: Kirk RW (Ed.), Current Veterinary therapy X. Saunders, Philadephia, pp: 369376.

15. Johnson LR, Kass PH (2009) Effect of sample collection methodology on nasal culture results in cats. J Feline Med Surg 11(8): 645-649.

16. Trow AV, Rozanski EA, Tidwell AS (2008) Primary mycoplasma pneumonia associated with reversible respiratory failure in a cat. J Feline Med Surg 10(4): 398-402.

17. German AJ, Cannon MJ, Dye C (2005) Oesophageal strictures in cats associated with doxycycline therapy. J Feline Med Surg 7(1): 33-41.

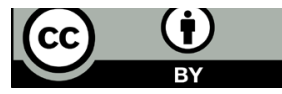

This work is licensed under Creative Commons Attribution 4.0 License DOI: 10.19080/OAJS.2018.09.555764
18. Dear JD (2014) Bacterial pneumonia in dogs and cats. Vet Clin North Am Small Anim Pract 44(1): 143-159.

19. Stillion JR, Letendre JAA (2015) Clinical review of the pathophysiology, diagnosis, and treatment of pyothorax in dogs and cats. J Vet Emerg Crit Care (San Antonio) 25(1): 113-129.

20. Rooney MB, Monnet E (2002) Medical and surgical treatment of pyothorax in dogs: 26 cases (1991-2001). J Am Vet Med Assoc 221(1) 86-92.

\section{Your next submission with Juniper Publishers} will reach you the below assets

- Quality Editorial service

- Swift Peer Review

- Reprints availability

- E-prints Service

- Manuscript Podcast for convenient understanding

- Global attainment for your research

- Manuscript accessibility in different formats

( Pdf, E-pub, Full Text, Audio)

- Unceasing customer service

Track the below URL for one-step submission https://juniperpublishers.com/online-submission.php 